This work is licensed under a Creative Commons Attribution 4.0 International License.

Ovaj rad dostupan je za upotrebu pod međunarodnom licencom Creative Commons Attribution 4.0.

https://doi.org/10.31820/f.31.2.5

Tena Šinjori

\title{
SOCIOLINGVISTIČKA ANALIZA PREDGOVORA ČEŠKIH I HRVATSKIH JEDNOJEZIČNIH RJEČNIKA
}

Tena Šinjori, Sveučilište u Zagrebu, Filozofski fakultet, tsinjori@ffzg.hr, Zagreb

izvorni znanstveni članak

UDK 811.162.3'373

811.163 .42 '373

rukopis primljen: 2. rujna 2019; prihvaćen za tisak: 5. prosinca 2019.

U radu se kritički pristupa poimanju rječnika kao neutralnog izvora znanja. Rječnik se proučava kao zbirka tragova koje u njemu ostavljaju autori i sredina u kojoj nastaje.

Cilj je ovoga istraživanja otkriti kako su se u jednojezičnim objasnidbenim rječnicima hrvatskoga i češkog jezika odrazile razlike u društvenom uređenju dviju bivših socijalistički uređenih država: SFRJ i Čehoslovačke. Provedena je sociolingvistička poredbena analiza prvenstveno predgovora čeških i hrvatskih rječnika objavljenih tijekom socijalističkog razdoblja. Posebna pozornost posvećena je dijelovima teksta koji se odnose na društvenu zbilju i okolnosti nastanka rječnika. Glavna pretpostavka bila je da će socijalizmu i njegovim utjecajima na leksikografiju više pozornosti biti posvećeno u češkim rječnicima, dok će hrvatski rječnici u većoj mjeri obrađivati temu jezika kao indeksa nacionalnoga identiteta.

Analiza dobivenih podataka bolje rasvjetljuje položaj leksikografske djelatnosti u uspoređivanim društvima i opisuje utjecaje koje na nju imaju nejezikoslovne (ekonomske, političke, ideološke) okolnosti. Rezultati potvrđuju hipotezu o prisutnosti teme socijalizma u češkim rječnicima i teme jezika kao indeksa nacionalnoga identiteta u hrvatskim rječnicima.

Ključne riječi: češka leksikografija; hrvatska leksikografija; ideologija; socijalizam; nacija 


\section{Uvod}

Društveno uređenje i politički ustroj uvjetuju cjelokupnu društvenu djelatnost. Utjecaji političkoga sustava osobito su vidljivi u znanostima koje su po svojoj naravi čvrsto povezane $s$ društvenim promjenama. Leksikografija, koja nastoji popisati riječi i u skladu s duhom vremena definirati njihovo značenje, izuzetno ovisi o promjenama u društvu. Zbog tijesne povezanosti $s$ vremenom nastanka rječnici se mogu čitati kao povijesni izvori posebne vrste. To osobito vrijedi za rječnike nastale $u$ razdobljima intenzivnih društvenih previranja kada su promjene u leksiku najizraženije.

Sociolingvistički pogled na rječnike pruža vrijedne informacije o načinima na koje društvo danoga vremena utječe na lingvističku djelatnost te o položaju leksikografske znanosti u određenom trenutku. S druge strane, rječnici su kao referentna građa u kojoj korisnici traže odgovore na pitanja o značenju pojava u svijetu prepoznati kao jedan od alata moći zbog čega je mnogima važno upravljati njihovim nastankom. Rječnici su zato i izvor informacija o izvanjezičnom diskursu svojega nastanka. Zbog zahtjevnosti i dugotrajnosti postupka njihove izrade u nekim su rječnicima vidljivi tragovi različitih političkih sustava.

Države kojima su u drugoj polovici 20. st. pripadale današnja Češka i Hrvatska prošle su sličnim putem izmjene vladajućih sustava. Nakon Drugoga svjetskog rata u obje je države uvedeno socijalističko društveno uređenje. Iako temeljeno na istoj filozofiji, uređenje u SFRJ i u Čehoslovačkoj po mnogočemu se razlikovalo. Cilj je istraživanja, čija je prva faza obrađena u ovome članku, usporediti leksikografske odraze dviju velikih društvenih prekretnica zajedničkih češkoj i hrvatskoj povijesti uspostavu socijalističke vlasti nakon Drugoga svjetskog rata i pad socijalističkog sustava devedesetih godina 20. stoljeća. Iako su to bili politički srodni procesi, u dvjema su se sredinama odvijali na različite načine. Namjera je istražiti kakve su razlike vidljive u obradi leksikografskih natuknica od općeg društvenog značaja. Neke su od njih: sloboda, samostalnost, republika. Prvi je korak prema tom istraživanju analiza popratnih tekstova izabranih jednojezičnih objasnidbenih rječnika izdanih nakon 1943. godine (godina uspostave socijalističke vlasti u SFRJ1). Proučavanjem sličnosti i razlika u međuigri društva i leksikografije kod dvaju naroda u

1 Komunistička vlast u Čehoslovačkoj uspostavljena je kasnije, 1948. godine. 
radu se problematizira položaj leksikografije kao znanosti u promatranom vremenu.

U poglavlju koje slijedi navedena su glavna teorijska polazišta za promatranje rječnika kao povijesnoga izvora. U trećem su poglavlju predstavljeni primarni izvori (jednojezični rječnici češkoga i hrvatskoga jezika izdani tijekom druge polovice 20. st.) i korištena metodologija. Analiza je podijeljena u sedam odlomaka koji proizlaze iz indukcijskog grupiranja podataka. U završnom su dijelu navedeni zaključci analize i plan za moguće daljnje istraživanje.

\section{Teorijski okvir. Idejna polazišta.}

Jednojezični objasnidbeni rječnici referentna su građa u kojoj korisnici traže značenja riječi kojima označavaju pojave u jezičnom i izvanjezičnom svijetu. Pristupaju im kao neutralnom izvoru objektivnoga znanja, što je u srži problematično. Svi rječnici, osobito oni iz vremena prije razvoja korpusne lingvistike, čuvaju tragove svojih tvoraca - autora, urednika i sredine u kojoj su nastali, a to otvara pitanje objektivnosti leksikografske građe. Antun Vujić, baveći se primarno enciklopedijskom leksikografijom, ovom problemu pristupa uzimajući u obzir kriterij trajnosti. Piše kako se svaki leksikografski sustav mora zasnivati na onim spoznajama koje su stekle institucionalnu i javnu legitimaciju. Budući da su institucionalna i javna legitimacija zadobivene u nekom povijesnom trenutku, o tom su trenutku ovisne i ne moraju vrijediti u nekom drugom. Vujić piše: „...leksikografske činjenice su upravo takve činjenice čija se objektivnost zasniva na odnosu s drugim činjenicama i na mogućnosti da taj odnos bude provjeravan znanstvenom leksikografskom procedurom" (Vujić 2013: 18). Zadaća je leksikografije da prepozna činjenice usklađene sa zbiljom danoga vremena i na znanstveni ih način obradi.

Pitanje znanstvenosti i autonomnosti leksikografije Vujić rješava postavljanjem vrijednosnoga modela znanosti i društva: razvoj svake znanosti pripada polju društvenih vrijednosti, ali unutar toga polja znanost se razvija samostalno, a svojim razvojem omogućava boljitak i samom polju društvenih vrijednosti. Ako se ne može razvijati samostalno, postaje pseudoznanost. Leksikografija se, budući da znanje prilagođava korisniku (ima posredničku ulogu), lako može okliznuti u pseudoznanost. Posrednički proces ostavlja prostor za individualne i kolektivne intervencije te mnoge krivotvorine. Dok se nenamjerne krivotvorine mogu tretirati kao prostor za 
napredak te stoga kao prihvatljive, namjerne (one uzrokovane političkim, ideološkim, kulturnim i drugim zahtjevima) nisu prihvatljive jer narušavaju autonomiju leksikografije kao znanosti (Vujić 2013: 17). Posrednička uloga leksikografije osigurava prostor za neprestanu budnost i usklađenost s vremenom i potrebama društva u kojem rječnik nastaje. ${ }^{2}$ Važno je istaknuti da posrednička uloga leksikografije i njezina društvena uvjetovanost ne umanjuju njezinu vrijednost kao znanosti:

'...cilj neke poželjne leksikografije i ne može biti u likvidaciji njene društvene determiniranosti $u$ smislu odbacivanja vrijednosnoga društvenog sustava. Leksikograf je čovjek, kao što je i leksikografija društvena institucija; lišiti ih vrijednosnih određenja značilo bi lišiti ih samih ljudskih, odnosno društvenih temelja.' (Vujić 2013: 17)

Negativan utjecaj na leksikografiju imaju različite vrste pritisaka (politički, ideološki i drugi, u Vujićevu shvaćanju to su namjerne krivotvorine) koje leksikografiji onemogućuju ostvarivanje autonomnosti: „...ukidanje autonomnosti te strukture [autonomne strukture leksikografske metode] voluntarizmom ideoloških činilaca vodi u pseudoznanost, s povratnim efektom gubljenja mjesta u vrijednosnom modelu znanosti i društva" (Vujić 2013: 17). Ta je teza idejno polazište za ostvarivanje glavne zadaće ovoga članka: pronalazak negativnih utjecaja na leksikografiju tematiziranih u samim leksikografskim djelima.

Rječnici se mijenjaju usporedno s promjenama u leksiku. Tijekom povijesnih previranja kao što su ratovi ili smjene političkog sustava promjene u leksiku izraženije su: intenzivnije su interakcije između aktivnog i pasivnog leksika, česta su oživljavanja zastarjelih riječi, stvaraju se neologizmi, česte su semantičke promjene poput proširivanja značenja leksema. Događaju se i promjene u poimanju stvarnosti, a time i u tumačenju pojmova važnih za čitavu zajednicu. Među njih T. Dickins svrstava nazive važnih povijesnih prekretnica. Proučava na koji su način ključni događaji u češkoj povijesti obrađeni u različitim rječnicima tijekom

2 Ovaj je argument izuzetno važan kod kritike suvremene hrvatske leksikografije koju iznosi B. Tafra. Kao jedan od razloga neadekvatnosti novijih hrvatskih rječnika (Anić, Veliki Anić) ističe korištenje metode kompilacije starijih rječnika kod stvaranja novoga rječnika. Copy-Paste metodom u općeupotrebne rječnike hrvatskoga jezika ulaze riječi koje s jezikom i vremenom izlaska rječnika nemaju mnogo zajedničkoga (Tafra 2005: 171). 
20. st. (Dickins 2012). U drugoj studiji (Dickins 2000) bavi se promjenama rječničkih definicija u četirima izdanjima istoga rječnika pri čemu svako izdanje nastoji promatrati iz perspektive specifične političke situacije u kojem je nastalo (radi se o izdanjima iz predratne 1937., ratne 1941., poslijeratne 1946. i posljednjem izdanju nastalom 1952., četiri godine nakon dolaska komunista na vlast). Dickinsove studije pokazale su se kao inspirativan oslonac za čitanje rječnika kao povijesnog izvora te vrijedan izvor podataka o češkim rječnicima.

\section{Metodologija i izvori}

U središtu su zanimanja ovoga rada predgovori čeških i hrvatskih jednojezičnih objasnidbenih rječnika izdanih nakon 1943. godine. S obzirom na to da su neki rječnici izdani nakon 1943. višesveščani te su neki svesci izašli ranije ili su njihova ranija izdanja izašla prije 1943., a kasnija nakon 1943., u članku su obrađeni i rječnici koji su počeli izlaziti prije Drugoga svjetskog rata što je u konačnici pružilo uvid i u situaciju prije 1943. Osobita je pozornost posvećena rječnicima koji su izdani neposredno nakon pada komunističkoga sustava 90-ih, no zbog nevelike tiskane leksikografske produkcije i težnje za što obuhvatnijim pogledom, obrađeni su i rječnici nastali kasnije, do sadašnjeg trenutka. U promatranom razdoblju izašli su sljedeći rječnici češkoga jezika:

- Přiruční slovník jazyka českého (1935 - 1957, digitaliziran 2007) (u nastavku: PSJČ)

- Slovníkjazyka českého (1937, 1941, 1946, 1952) (u nastavku: SJČ)

- Slovník spisovného jazyka českého (1960 - 1971, 1989, digitaliziran 2011.) (u nastavku: SSJČ)

- Slovník spisovné češtiny pro školu a veřejnost (1978, 1994, 2003, 2004, 2005, 2009) (u nastavku: SSČ)

U istom su razdoblju izašli sljedeći jednojezični rječnici hrvatskoga (i „hrvatskosrpskoga”) jezika:

- Rječnik hrvatskoga ili srpskoga jezika (1880 - 1976) (u nastavku: Akademijin rječnik)

- Rječnik hrvatskosrpskoga književnog jezika (1967) (u nastavku: RHSKJ)

- Rječnik hrvatskoga jezika (1991, 1994, 1998) (u nastavku: Anić) 
- Veliki rječnik hrvatskoga jezika (2003) (u nastavku: Veliki Anić)

- Rječnik hrvatskoga jezika (2000) (u nastavku: LZMKŠK)

- Veliki rječnik hrvatskog standardnog jezika (2015) (u nastavku: VRH)

Analiziraju se prvenstveno predgovori spomenutih rječnika. Ostali dijelovi (komentari, upute za korištenje rječnika, popis stilskih odrednica) spomenuti su samo ako utvrđuju odnos rječnika i izvanjezičnoga konteksta njegova nastanka. Iznimno se analizira i Katičićeva recenzija VRH-a, zato što je sastavni dio rječnika. Akademijin rječnik zbog dvostrukog statusa (povijesnog i općeupotrebnog rječnika) u ovom radu zauzima posebno mjesto. Počeo je izlaziti 1878, dakle više od pola stoljeća prije određene polazišne godine za ovo istraživanje, ali je rad na njemu dovršen 1975. (što ulazi u zadani vremenski okvir istraživanja). Radi postizanja cjelovitog uvida u rječnik, analizirani su svi popratni tekstovi tiskani u posljednjem svesku od kojih su neki izašli ranije u drugim svescima ili publikacijama. Ovdje se navode redoslijedom prema kojem su tiskani u posljednjem svesku: Daničićev predgovor "Ogledu” (oglednom svesku danom javnosti na prosudbu) iz 1878, „Objava o daljem obrađivanju rječnika” iz 1910. (kao autor navodi se JAZU), „Nastavak rada na Rječniku” (kao autor se navodi Filološki odjel JAZU), Maretićeve „Crtice o Rječniku naše Akademije” iz 1916, „Nove crtice o Rječniku” Slavka Pavešića i Zore Reizer iz 1965, „Pogovor” S. Pavešića i tekst Lj. Jonkea „O značenju i upotrebi Akademijina Rječnika”.

Posebna je pozornost posvećena dijelovima predgovora koji tematiziraju društvenu zbilju, odnos jezika i društva, ulogu leksikografije u tvorbi jezičnoga i nacionalnog identiteta, leksikografiju kao područje ideološkoga sukoba, odnosno dijelovima teksta koji potvrđuju status leksikografije kao znanosti koja se ostvaruje u neprestanom prožimanju društvene i lingvističke zbilje. Indukcijskom metodom utvrđeno je sedam područja koja se u predgovorima implicitno ili eksplicitno tematiziraju:

1. okolnosti izdavanja (institucije, skupno ili individualno autorstvo, suradnici, financije)

2. odnos vlasti prema leksikografiji

3. leksikografska tradicija (zatečeno stanje, potrebe i perspektiva)

3 Citati iz Akademijina rječnika za potrebe ovoga rada prilagođeni su suvremenoj pravopisnoj normi. Đuro Daničić predložio je reformu pravopisa koju Akademijin rječnik poštuje do samog kraja izdavanja, iako predložene promjene (s iznimkom grafema đ) nisu zaživjele u upotrebi. 
4. jezična kultura (uloga rječnika u standardizacijskom procesu)

5. društvena zbilja

6. odnos jezika i društva

7. uloga leksikografije u konstruiranju nacionalnoga identiteta.

\section{Analiza}

\subsection{Okolnosti izdavanja}

Okolnosti koje su pratile izdavanje rječnika nisu tematizirane u predgovorima svih rječnika. Opsežno su opisane u starijim rječnicima, dok su u novijima uglavnom spomenuti samo podaci o urednicima i, u nekima, o izvoru financiranja.

Najviše podataka o okolnostima izdavanja navodi Akademijin rječnik. Daničić u Ogledu piše kako je JAZU na njegovu inicijativu započela rad na Rječniku. U Crticama se Maretić osvrće na ispisivače rječničke građe. Uz to što navodi njihova imena i zasluge, kritizira šture upute koje su ispisivači dobili od uredništva i opisuje nedostatke procesa sakupljanja građe (generalna neujednačenost: nejednak broj primjera za pojedine natuknice, mnogo mogućnosti za pogreške, gubljenje listića i sl.) (16-32). U Objavi se navodi kako je rječnik preopširan i da se to mora promijeniti, između ostalog, i zbog toga da bi se smanjili troškovi (11-12). U Nastavku se spominje kako je jedna od prvih zadaća JAZU nakon njezinog ponovnog osnivanja 1947. bila što prije nastaviti s radom na rječniku. Maretić opisuje financijsku pozadinu izdavanja rječnika naglašavajući kako se radi o izuzetno skupom poslu (do 1916. potrošeno je prema njegovoj procjeni 200.000 kruna), no ističe da "na to se akademija ne tuži i ne smije se tužiti” jer je osnovana kako bi financirala projekte koje se drugi zbog mogućih gubitaka ne usude financirati (52). Maretić spominje i biskupa Strossmayera koji je sve do svoje smrti svake godine izdvajao 1000 forinti za rječnik. S. Pavešić u Novim crticama piše kako je nakon 1947. rad na rječniku ubrzan te da od 1948. u njemu sudjeluje i novoosnovani Institut za jezik i književnost (55-56). U Pogovoru Pavišić popisuje urednike i suradnike koji su pridonijeli stvaranju rječnika. Uspoređuje i kritički vrednuje njihove pristupe i odluke (71-74).

Okolnosti izdavanja rječnika opširnije se opisuju u još samo dva rječnika: u češkom PSJČ (1935) i hrvatskom („hrvatskosrpskom”) RHSKJ (1967). Oba su rječnika u institucijama u kojima su nastajali imala posebnu 
važnost. Tako je Kancelariju za Rječnik češkoga jezika III. razred Češke akademije znanosti i umjetnosti osnovao upravo radi stvaranja jednojezičnog rječnika. Iz predgovora RHSKJ saznajemo da rječnik zajedno pišu članovi Matice hrvatske i Matice srpske (odatle i popularni naziv „Rječnik dviju matica") (Petrović 2006: 463). Iz predgovora saznajemo kako svaka od matica obrađuje natuknice za pola početnih slova i da rječnik izlazi u ekavskoj i ijekavskoj varijanti.

Predgovori rječnika novijega datuma navode vrlo šture informacije o okolnostima izdavanja. Anićevi rječnici $(1991 ; 1994)$ naglašavaju kako se izdavanje uspješno samo financiralo novcem od pretplata te da $u$ financiranju nije morao sudjelovati ni jedan državni fond. LZMKŠK navodi kako je rok za izdavanje rječnika bio vrlo kratak te da su 1996. nikle razmirice među članovima uredništva zbog čega je Jure Šonje imenovan novim glavnim urednikom.

\subsection{Odnos vlasti prema leksikografiji}

Pozitivan odnos vladajućih prema stvaranju rječnika spominje se samo u Akademijinu rječniku. Daničić piše kako se mogao posvetiti radu na rječniku jer je srpska vlada za to imala razumijevanja te mu je dopustila da neko vrijeme ne obavlja svoje obveze u Beogradu.

U rječnicima obaju jezika izdanim nakon smjene političkog uređenja spominje se cenzura prijašnjih sustava: nakon Drugog svjetskog rata (tematizirana je cenzura nacističkoga sustava) i nakon 1990-ih (cenzura komunističkih sustava). U SJČ (1946) spominje se kako su u rječniku izašle mnoge riječi koje zbog cenzure nisu mogle izaći u izdanju iz 1941. Gotovo 50 godina kasnije SSČ (1994) navodi kako drugo izdanje rječnika nije moglo izaći zbog zabrane "glavnoga u češkoj lingvistici” koji je na zabranu bio motiviran „stranačkim i osobnim razlozima”, dakle potaknut intervencijom s više razine komunističke vlasti (5). U predgovoru Anića (1991) navodi se kako je rad na rječniku počeo već 1969. (u kolektivu), ali je nakon sloma hrvatskoga proljeća 1971. zbog političkih pritisaka bio zaustavljen te je Anić do izdavanja rječnika 1991. nastavio raditi sam (VI). Odnos vlasti prema jeziku i posredno prema leksikografiji u predgovoru 1. izdanja Anića spominje se i kao sastavni dio objašnjenja uzroka lošemu stanju u hrvatskoj jednojezičnoj leksikografiji. Nakon spomena ideologija prisutnih na hrvatskom prostoru tijekom 20. st. navodi se: „U prirodi je tih totalitarizama da podvrgavaju i posvajaju javni život (a ponekad i privatni) čovjeka 
pojedinca i cijelih naroda. Vrše nasilje i nad jezikom pretvarajući ga u svoje političko oruđe (ili oružje)" (V).

Češki rječnici komunističke ere ne skrivaju da su inspirirani sovjetskim načinom postupanja prema nacionalnom jeziku. Tako se SJČ (1952) osvrće na predsjednika SSSR-a J. V. Staljina te ističe kako se prema češkom treba ponašati na način na koji Staljin zahtijeva da se ponaša prema ruskom - $u$ skladu s novim poretkom (IX-X).

\subsection{Leksikografska tradicija}

Leksikografska je tradicija spomenuta u gotovo svim rječnicima. S. Pavešić navodi stare višejezične rječnike kao izvor materijala za Akademijin rječnik. Lj. Jonke o Akademijinu rječniku piše: „To je jedno od najvećih djela svjetske leksikografije i najveće slavensko leksikografsko djelo" (77). Dalje piše kako je Rječnik utjecao na izdavanje pravopisa 1892, Maretićeve gramatike 1899. te Broz-Ivekovićeva rječnika 1901. (81-82).

Predgovor RHSKJ (1967) odiše manjom euforijom kada piše o Akademijinu rječniku. Ističe kako je neodgovarajuć zbog svojega opsega i sporosti izlaženja. I u češkom najstarijem rječniku PSJČ (1935) ističe se neadekvatnost dotad izdanih rječnika: Kottov i Jungmannov rječnik na koje se idejno nadovezuje PSJČ dvojezični su i, prema riječima iz predgovora, zastarjeli, zbog čega ne mogu udovoljiti potrebama suvremenih govornika (VII). Izdanja SJČ $(1946 ; 1952)$ navode kako rasprodanost izdanja rječnika iz ratne 1941. sugerira potrebu za praktičnim rječnikom. U Anićevu rječniku (1991) ističe se kako je razvoj hrvatske leksikografije nakon BrozIvekovićeva rječnika bio nezadovoljavajuć, za što je prije svega odgovorna nepovoljna politička situacija (V).

\subsection{Jezična kultura}

Važnost leksikografije u pitanjima jezične kulture i standardizacije jezika istaknuta je u predgovorima gotovo svih analiziranih rječnika. U nekim rječnicima stav se izražava eksplicitno, u drugima pak implicitno, objašnjenjem leksikografskog postupka u pitanjima spornim za standardizacijski proces (izbor natuknica, stav prema riječima stranog podrijetla, stav prema leksiku na marginama sustava, demokratizaciji rječnika, stilskim odrednicama...)

Sporna pitanja kod standardizacije opsežno su obrađena u Akademijinu rječniku pri čemu je posebna rasprava vođena o izvorima iz kojih bi se 
trebala crpsti građa za rječnik, posredno i za uporabnu normu književnoga jezika. Polemiku je izazvalo marginaliziranje kajkavskoga narječja. Daničić u Ogledu piše kako rječnik sadrži riječi iz književnoga jezika, iz narodnoga jezika i posuđenice iz drugih jezika. No, uz riječi iz drugih narječja u rječnik uključuje samo one kajkavske riječi koje su „ušle u običaj” (6). Maretić u Crticama kritizira odluku o izbacivanju kajkavskoga iz rječnika te napominje kako bi bolje bilo rječnik podijeliti na dva dijela: jedan u kojem bi bile riječi iz narječja i drugi - rječnik suvremenoga jezika (32-33). Nadalje, Maretić piše da iz rječnika izbacuje tzv. „srpskoslovenske riječi” iz djela srpskih pisaca tvrdeći da one nikad nisu bile dio narodnoga jezika (41). Izvori za ekscerpciju građe nisu jedina Daničićeva odluka koju Maretić kritizira. Spornom Maretić smatra i reformu pravopisa kojom se uvode nova slova po uzoru na ćirilicu (36-37).

Zbog svjesnih i promišljenih odluka o tome koje će jezične formacije u rječniku biti zastupljene, a koje ne, Lj. Jonke piše kako se Akademijin rječnik može promatrati kao normativan, a ne informativan priručnik. Zbog normativnih odluka koje su kasnije u književnom jeziku zaista uvriježene, Jonke piše da se Akademijinu rječniku pripisuje „pionirsko značenje za utvrđivanje novoga književnog jezika u Hrvatskoj" (78). U nastavku napominje kako se bez Akademijina rječnika književni jezik ne bi ustalio jednako brzo (82). Dok izbacivanju ilirskih djela 19. st. Jonke pripisuje zasluge za utvrđivanje književnoga jezika, u Pavešićevu Pogovoru spomenut je komentar A. Vebera koji taj Daničićev postupak ne promatra blagonaklono, već ga smatra nedostatkom Rječnika. Veber, dakako, piše mnogo prije Jonkea kada utjecaj Rječnika i put razvoja književnoga jezika nije bio jasan. Iz ovoga je primjera očito da se pozitivnima ocjenjuju standardizacijski postupci koji ispravno predviđaju kako će se književni jezik razvijati. Jonke nadalje upozorava da Akademijin rječnik zbog svog djelomično povijesnog karaktera ne bi trebao biti mjerilo za ulazak riječi u književni jezik (78-79).

Izravno se na standardizaciju osvrću RHSKJ i VRH u kojima se rječnici tretiraju kao nužna sredstva za razvoj književnoga jezika. Predgovor RHSKJ citira 5. točku Novosadskoga dogovora: „Radi iskorišćavanja cjelokupnog rječničkog blaga našeg jezika i njegovog pravilnog i punog razvitka neophodno [je] potrebna izrada priručnog rječnika srpskohrvatskog književnog jezika” (8). R. Katičić u recenziji VRH-a piše: „,VRH] je toliko opsežno i važno nacionalno djelo da će se na temelju njega moći standardizirati hrvatski jezik u školama, na sveučilištima, i u sveukupnoj stručnoj i javnoj 
upotrebi" (VII). O standardizaciji u predgovoru svojemu rječniku piše i Anić. Spominje odluke o spektru riječi koje su u rječnik uvrštene pa navodi kako rječnik nastoji obuhvatiti što veći dio hrvatskoga jezičnog standarda, ali ne izostavlja ni uvriježene tuđice pa čak ni riječi „nametnute hrvatskom jeziku u nekom razdoblju”, npr. 1941.-1945., upozoravajući pritom na odnos tih riječi prema standardu, odnosno na njihovo podrijetlo (VI).

U dvama se hrvatskim rječnicima eksplicitno propitkuju i pitanja jezične kulture te načela standardizacije. U izdanju Anića iz 1994. u uputama Kako se služiti rječnikom navodi se da se kod izbora natuknica slijedilo načelo „komunikativne valjanosti, tj. prihvaćenosti u jeziku izvornoga hrvatskog govornika." Dalje se ističe kako rječnik nije zbir najboljih riječi, nego svih riječi - onih s kojima se govornik nekog jezika može susresti. Katičić u recenziji VRH-a objašnjava kako VRH ništa ne propisuje, ali objašnjava koja je upotreba određene riječi stilski neutralna „a upravo to i jest jezični standard: jednoznačno utvrđivanje stilski neutralne upotrebe", zaključuje.

Među češkim rječnicima svoje standardizacijske tendencije jasno izražava PSJČ (1935) i one su u skladu s vremenom početka rada na rječniku kad još nije postojao jednojezični objasnidbeni rječnik češkoga jezika. Pobrojane su namjere rječnika: obuhvatiti suvremeni leksik, objasniti ga domaćim riječima, usustaviti normu, razvijati sinonimiju i frazeologiju, riječi opisati semantički i stilski (VII).

U SJČ $(1937 ; 1946 ; 1952)$ istaknuto je da rječnik sadrži i neknjiževno rječničko blago. Sva tri izdanja iznose i stav autora rječnika prema jezičnoj ispravnosti. Rječnik iz 1937. tako navodi da se uz načela povijesne i teorijske ispravnosti u rječniku poštuju i „ustaljen običaj i potrebe književnoga govora" (VI). Izdanja iz 1946. i 1952. ne inzistiraju na književnom govoru. Autori ističu da su u rječnik uvrštene i neispravne riječi jer su promatrane s funkcionalnog stajališta. Uvrštavanjem tih riječi autori ih brane od mogućih prigovora o neispravnosti (SJČ 1946, VII; SJČ 1952, VII). Posljednja tvrdnja ilustrira i status rječnika kao priručnika-autoriteta kod odlučivanja o prihvatljivim izražajnim sredstvima.

U kasnije izdanim rječnicima pozornost je uglavnom posvećena dinamici suvremenoga jezika i prepoznavanju progresivnih riječi te onih koje se povlače iz uporabe. U predgovoru SSJČ (1960) spominje se kako rječnik obrađuje građu suvremenoga književnog jezika, ali i terminologiju novih znanosti. Također se ističe kako je stari leksik uvršten u rječnik, 
samo ako se pojavljuje u značajnim književnim djelima. Rječnik nastoji normu književnog jezika razvijati i usustavljivati i u novim područjima rada i mišljenja (V). SSČ (1994) ističe kako je u rječničku građu uključen i leksik koji nije dio norme: elementi slenga, zastarjele riječi, neologizmi i strane riječi za koje se predviđa da će se u jeziku zadržati zbog jačanja međunarodnih odnosa (6).

\subsection{Društvena zbilja}

Kao važan čimbenik za osvješćivanje potrebe za stvaranjem rječnika hrvatskoga („hrvatskosrpskog”) jezika Pavešić u Pogovoru Akademijinu rječniku navodi činjenicu da su hrvatske zemlje bile dio Austro-Ugarske Monarhije i da je rječnik u tim okolnostima bio jedan vid otpora mađarizaciji i germanizaciji (62).

U PSJČ (1935) stvaranje rječnika opravdava se razvojem mnogih znanosti i povećanom potrebom za stvaranjem nove terminologije što se ponavlja i u češkim rječnicima kasnijih razdoblja, osobito u SJČ iz 1952. u kojemu se razvoj tehnike i znanosti spominje usporedno s uspostavom socijalističkoga uređenja:

'Rječnik se [...] dopunio značajnim brojem novih riječi i izraza nastalih kao posljedica razvoja nove socijalističke proizvodnje, nastanka nove države, nove socijalističke kulture, novog društvenog života, morala i konačno rasta tehnike i znanosti. ${ }^{4}$ (IX)

Rat kao okosnica svekolikog djelovanja izravno se spominje u nekoliko rječnika. Pavešić u Pogovoru Akademijinu rječniku objašnjava kako je rad na rječniku 1938. bio zaustavljen jer

'rat je bio pred vratima i uskoro je došao: okupator i njegovi sateliti ušli su u zemlju. Sve institucije koje nisu služile njegovu interesu bile su likvidirane, a s njima i Jugoslavenska akademija znanosti i umjetnosti, izdavač rječnika. Tek tri godine po svršetku rata, nakon perioda obnove i oporavljanja od pretrpljenoga pustošenja, mogla je biti obnovljena i Akademija.' (72)

4 Citati iz čeških rječnika navode se u prijevodu autorice. 
U predgovoru 1. izdanja Anićeva rječnika koji je dovršen ratne 1991. izdavač piše: „Ipak, to nije rječnik rata, niti je ratni rječnik: nije na brzinu ratnički improviziran, niti se rječnikom bilo protiv koga ratuje."

Češki SJČ (1952), SSJČ (1960; 1989) i SSČ (1994) bilježe promjene u rječniku nastale uslijed uspostavljanja (SJČ i SSJČ), odnosno dokidanja (SSČ) socijalizma. SJČ (1952) tako navodi:

'Radosni, u čitavoj našoj povijesti neviđeni polet svekolikog društvenog napretka povezan s pobjedničkim putem prema novome poretku, socijalističkom, odrazio se vrlo izraženo $u$ rječniku češkoga jezika koji je povezan s mišljenjem, a istovremeno sa svekolikom djelatnosti svih njegovih korisnika.' (IX)

SSJČ: „[...] polet gospodarskog života, kulture, znanosti i tehnike sa sobom donosi i nezamislivo obogaćenje našeg književnog jezika, zajedničkog čitavom narodu" (V). U 2. izdanju SSČ koje izlazi nakon pada socijalističkoga sustava i nakon uspostave samostalne Republike Češke istaknuto je kako je rječnik promijenjen u skladu s novim poretkom i novim pravopisom koji je u međuvremenu stupio na snagu. Slijedom tih promjena u rječnik su ušle i riječi stranoga podrijetla za koje su urednici predvidjeli da će se u jeziku održati zbog očekivanog jačanja međunarodnih odnosa nakon 1989. (6).

\subsection{Odnos jezika i društva}

Odnos jezika i društva naglašavao se u češkim rječnicima u razdobljima nakon uspostave i nakon pada socijalističkoga režima. Jezik se u socijalističkom periodu povezivao s marksistički shvaćenom proizvodnjom. Tako SJČ (1952) u predgovoru citira ulomak iz Staljinovih teza u kojem autor ističe kako jezik omogućuje razmjenu stavova bez koje je nemoguća društvena proizvodnja, „...bez jezika društvo zaustavlja proizvodnju, raspada se i prestaje postojati kao društvo" (X). SSJČ (1960) ističe kako demokratizacija i razvoj društva u doba socijalizma povisuju značaj književnoga jezika te on postaje vlasništvom svih pripadnika naroda. Povećanje stupnja demokratičnosti književnoga jezika smatra se zadaćom leksikografa, upravo bi leksikograf korisnicima književnog jezika „čiji broj se stalno povećava, osobito među radničkom klasom" trebao omogućiti lakše snalaženje u promjenama književnoga jezika (SJČ 1952: X). Rječnici 
socijalističkoga razdoblja naglašavaju kako je književni jezik kulturno dobro koje pripada svim govornicima, ne samo izabranim slojevima.

Rječnik se nadalje smatra mjestom spajanja tradicije narodnoga života i razvoja u suvremenom dobu te zbog toga i nužnim preduvjetom za dovršenje „kulturne revolucije.” SSČ (1994) piše kako rječnik odražava stanje kolektiva, njegovu društvenu i radničku raslojenost te je dokaz njegovih stremljenja (5). Isti rječnik naglašava i kako novi, postsocijalistički poredak ne donosi samo nove leksičke jedinice, nego i mijenja odnos među značenjima i značajem već postojećih. U 2. izdanju SSČ-a kao ključni nazivi novoga poretka ističu se: demokracija, sloboda, pluralitet nasuprot nazivima koji su bili u središtu pozornosti tijekom socijalističkoga uređenja: diktatura, proletarijat (5). Novo razumijevanje starih pojmova nakon promjena društvenog uređenja spominje i Jonke u tekstu $O$ značenju $i$ upotrebi Akademijina rječnika (1975):

'...dopuštajući veliku iscrpnost i vremensku otegnutost, pojedini dijelovi [Rječnika] donekle zastaruju u tumačenjima jezične teorije i društvenih nauka. Kao primjer mogla bi se navesti obrada riječi Hrvat, Jugoslaven i Jugoslavija (istaknula T.Š.) [...] Dakako, opće riječi nisu tako podložne promjenama. Najnovije doba može im dodati po koje specijalno značenje, ali suvremenicima to nije tajna, oni to lako pridodaju.' (80)

Jonke pravi razliku između općih riječi i onih koje nisu opće. Iz njegova je objašnjenja jasno da su opće one riječi čije značenje u manjoj mjeri ovisi o protoku vremena i promjenama u društvu. Kao osobito osjetljivi na društvene promjene navedeni su nazivi nacionalnosti i država koji nakon svake smjene političkoga sustava dobivaju novo značenje.

\subsection{Uloga leksikografije $u$ konstruiranju nacionalnoga identiteta}

Uloga rječnika u konstruiranju nacionalnoga identiteta naglašavana je u svim promatranim razdobljima. Početak izlaska najstarijeg, Akademijina rječnika, Pavešić u Pogovoru povezuje s položajem hrvatskoga jezika unutar Austro-Ugarske Monarhije. Jedna od uloga rječnika na početku izdavanja prema njegovu mišljenju bila je da ojača nacionalnu svijest Hrvata: rječnik bi u okolnostima mađarizacije i germanizacije trebao pokazati „veliku starinu hrvatske kulture i sposobnost hrvatskoga jezika da izrazi sve što je koji autor u svoje vrijeme želio izraziti" (62). 
Borba za autonomnost i suverenitet hrvatskoga književnog jezika u kasnijim je razdobljima poprimila druga obilježja. Pavešić prvog urednika Akademijina rječnika Đ. Daničića opisuje sljedećim riječima: „...oduševljeni pristaša i branilac ideje Vuka Karadžića o pučkom jeziku štokavskoga područja kao jedinstvenom književnom jeziku za Srbe i Hrvate" (62). O vrelima rječničke građe piše: „Izvori koje je Daničić uzeo kao osnovu za Rječnik odraz su [...] težnje za nacionalnom afirmacijom." Objašnjava kako se radi o jezičnom materijalu hrvatskog i srpskog jezika od najstarijih zapisa do polovice 19. st. (62). Ranije je spomenuta 5. točka Novosadskoga dogovora navedena u predgovoru RHSKJ prema kojoj se ističe potreba „naših” naroda za rječnikom „našeg” jezika. Hrvatski i srpski narod određuju se kao različiti, ali se jezik tretira kao zajednički.

Ideološka značenja koja su se jeziku pripisivala u različitim periodima 20. st. problematizirana su u predgovoru Anićeva rječnika iz 1991.: „Kroz jezik su se vodile ideološke borbe, pravi mali ratovi, s taloženjem inhibicija, animoziteta i predrasuda, koje su zamagljivale jasan pogled na probleme samoga jezika." Isti predgovor naglašava i kako se jezik prirodno razvija samo kad je oslobođen "političke instrumentalizacije [...], ne trebaju mu samoizolacionističke barijere prema drugim kulturama i jezicima, niti prisilne spone bilo s kime." Misli R. Katičića iz knjige Hrvatski jezik citirane u predgovoru VRH-a idejno se nadovezuju na Anića:

'Plovidba hrvatskog standardnog jezika nikad nije bila mirna i glatka [...] Osjećamo to i danas, u slobodnoj Hrvatskoj. Ipak, sve su stvarne zapreke prevladane. Treba još samo čvrsto osvijestiti da imamo hrvatski jezik, da ga imamo na svim razinama na kojima jezik postoji.' (V)

O rječniku Katičić u recenziji piše još da nije isključiv, „ali pruža onu pomoć pri izboru riječi koju je jezična politika srpskohrvatskog unitarizma pod svaku cijenu htjela uskratiti i onemogućiti [...]"

Uloga jezika u formiranju češkoga nacionalnog identiteta istaknuta je u najstarijem rječniku - PSJČ (1935). U predgovoru je istaknuto da se rječnik nadovezuje na sto godina stariji Jungmannov preporodni rječnik ${ }^{5}$ te

${ }^{5}$ Radi se o prvom dvojezičnom (češko-njemačkom) rječniku u kojem je češki polazišni jezik. Iako dvojezičan, rječnik ima objasnidbeni karakter, njemački jezik u njemu služi prvenstveno za objašnjenje značenja čeških riječi (Hladká 2005). 
da, baš kao i taj rječnik, ima narodnu ulogu. Rasprodanost ratnoga izdanja SJČ, u izdanju iz 1946. tumači se kao „radosni iskaz goruće povezanosti našega [češkoga] naroda u vremenu strašnog pritiska s jezikom kao jednim od najistaknutijih znakova češkoga duha" (VIII). U izdanju SJČ (1952) nakon socijalističkog prevrata naglašava se širenje uloga književnoga jezika i njegova povećana demokratičnost. Ta se obilježja povezuju s narodnim napretkom, ali se ne povezuju s češkom nacijom. U postsocijalističkom SSČ navodi se da se u rječniku oživljava leksik iz razdoblja Prve, Masarykove, Republike $^{6}$ (5).

\section{Rasprava}

Rječnici u objema državama za stagnaciju u razvoju leksikografije u nekim razdobljima krive političku situaciju. Anić piše kako su upravo nepovoljne političke prilike zaustavile razvoj leksikografije. SSČ (1994) okrivljava partijske odluke „Vodećeg u češkoj lingvistici” za zakašnjeli izlazak drugog izdanja rječnika. Čitanje predgovora nadalje pokazuje kako je zajedničko obilježje dviju leksikografskih tradicija - cenzura. U češkim rječnicima to je cenzura nacističkoga režima (saznajemo iz SJČ 1946), zatim socijalističkoga režima (saznajemo iz SSČ 1994). Anić piše kako je kolektivan rad na preteči njegova rječnika (pod vodstvom Lj. Jonkea) bio prekinut zbog političkoga pritiska nakon sloma Hrvatskog proljeća. Dok se u češkim rječnicima cenzura ticala izbora natuknica i definicija, u Hrvatskoj je, kao što svjedoči primjer projekta na čijem je čelu bio Lj. Jonke, bio zabranjen i sam rad na rječniku. ${ }^{7}$

Dvije vrste povijesnih događaja obilježile su leksikografiju obaju jezika. Prvi su od njih ratovi. Češki i hrvatski rječnici osvrću se na Drugi svjetski rat. U objema je kulturama on prekinuo rad na rječnicima u izradi (PSJČ, Akademijin rječnik). Ratna zbivanja ne utječu značajno jedino na SJČ (1941) koji uspijeva biti izdan, unatoč strahovladi Protektorata Češke i Moravske. Preostale dvije važne prekretnice tematizirane u predgovorima, a koje su utjecale i na strukturu glavnoga teksta rječnika, izmjene su

\footnotetext{
6 Tragovi Prve Republike bili su brisani iz rječnika nastalih tijekom nacističke okupacije, ali i u rječnicima socijalističkoga razdoblja.

7 Cenzura u izdanim rječnicima hrvatskoga jezika ticala se naziva jezika u naslovu rječnika, ali nije zadirala u sadržaj rječnika. O utjecaju ideologije na sadržaj rječnika odlučivao je njegov autor (Tafra 2005: 200). Cenzorskim postupkom iz čeških su rječnika izbacivane pojedine natuknice te dijelovi citata ili čak svi citati nepodobnih autora (Lexiko).
} 
političkog uređenja: uvođenje socijalizma i pad socijalizma. U predgovorima su opisane prvenstveno s perspektive promjene leksičke građe: promjene $u$ dinamici leksika, uvođenje novih riječi, ubrzano zastarijevanje nekih riječi, promjene u frekvenciji pojave, promjene u značenju.

Obogaćivanje leksičkoga sustava zbog razvoja znanosti i tehnologije tema je spomenuta u rječnicima gotovo svih razdoblja. Postoje, ipak, neke razlike u tumačenju promjena. Stariji rječnici (PSJČ) navode kako je proširivanje rječnika povezano s popularizacijom znanosti u slojevima prosječne inteligencije koji se više nego prije koriste stručnim terminima. Češki rječnici socijalističkoga vremena razvoj znanosti i tehnologije spominju u ovisnosti s uspostavom socijalističkoga društvenog uređenja. Promjene u leksiku u postsocijalističkom razdoblju SSČ povezuje s otvaranjem češkoga društva prema međunarodnoj zajednici.

Sljedeća je zajednička točka dviju leksikografija ideološka borba vođena posredstvom jezika i jezičnih pitanja. Čak tri analizirana češka rječnika spominju socijalizam kao važnu prekretnicu neodvojivu od društvenoga djelovanja, pa i od leksikografije. Socijalizam kao prekretnicu ne izdvaja ni jedan hrvatski rječnik. Komunizam (uz tuđinski hegemonizam, monarhistički apsolutizam i nacifašizam) ipak spominje Anić u nabrajaju totalitarnih ideologija i diktatura (V) koje su uz svjetske ratove nepovoljno djelovale na razvoj hrvatske leksikografije. Isticanje socijalizma kao povijesne prekretnice vidljivo je i u specifičnoj retorici rječnika nastalih nakon socijalističkog prevrata u Čehoslovačkoj. Jezik se u predgovorima neraskidivo povezuje s djelatnošću društva, zajedničkim dobrom nužnim za nastavak proizvodnje. Jezik se tumači kao sredstvo u službi naroda i napretka.

Leksikografija u službi stvaranja nacionalnog identiteta još je jedna zajednička tema predgovora rječnika dvaju jezika. U češkim rječnicima odražavaju se promjene stavova prema nacionalnom identitetu tijekom različitih faza 20. st. PSJČ, koji je počeo izlaziti tijekom Prve Republike, ističe svoju povezanost s preporodnim rječnikom Josefa Jungmanna te naglašava kako i sam ima narodni značaj. SSČ iz 1994. izražava povezanost s Prvom Republikom, napominje kako je u rječničku bazu uključen i leksik toga razdoblja (izbačen tijekom komunističke vladavine). Rječnici socijalističkoga razdoblja jezik i rječnike tretiraju kao javno dobro čitavoga naroda. Citiranjem Staljinovih teza o jeziku u tim se rječnicima naglašava povezanost češkoga jezika i naroda s ruskim. 
Pitanje nacionalnoga identiteta provlači se rječnicima hrvatskoga („hrvatskosrpskoga”) jezika od samih početaka razvoja jednojezične leksikografije. Hrvatski jezični identitet opisan je u opreci prema drugim jezicima. U najstarijem Akademijinu rječniku radi se o opreci prema njemačkom i mađarskom jeziku. U kasnije izdanim rječnicima jezični se identitet problematizira opisom približavanja ili udaljavanja hrvatskog i srpskog jezika.

\section{Zaključak}

Čitanje predgovora jednojezičnih objasnidbenih rječnika u zadanom povijesnom kontekstu pruža odgovor na dva pitanja: Kako promjene u društvu utječu na leksikografiju? Što leksikografija društvu u određenom trenutku znači? Poredbena analiza tipološki (ali i po društveno-povijesnom razvoju) bliskih jezika kao što su češki i hrvatski omogućuje otkrivanje suptilnih razlika u utjecaju društvenih i političkih procesa u dvjema sredinama na leksikografiju. Kod uočavanja tih razlika na umu valja imati nejednak broj izdanih (i analiziranih) rječnika u promatranim sredinama. Tako rječnicima komunističke vladavine moramo pristupiti imajući na umu činjenicu da su tijekom tog perioda u Čehoslovačkoj izdana dva jednosveščana (SJČ 1952, SSČ 1978) rječnika, dovršeno je izdavanje devetosveščanog PSJČ i u cijelosti je izdan četverosveščani SSJČ, a u istom razdoblju na hrvatskom tlu izdavana su samo dva djela koja pripadaju jednojezičnoj objasnidbenoj leksikografiji: prvi svezak Rječnika dviju matica (1967) i nekoliko svezaka povijesno-općeupotrebnog Akademijina rječnika.

Retorika predgovora čeških rječnika socijalističkoga razdoblja otkriva povezanost leksikografske prakse s marksističkom filozofijom i sovjetskom znanošću (citati iz Staljinovih Teza o jeziku!) što nije prisutno u rječnicima hrvatskoga jezika. Jednojezični su rječnici u objema kulturama tematizirani kao indeksi nacionalnoga identiteta, ali je važnost jezika i leksikografije u postizanju suverenosti nacije značajno više puta istaknuta u rječnicima hrvatskoga jezika.

U ovom je radu pozornost posvećena prvenstveno načinima na koji su u rječnicima eksplicitno prikazane povijesne (političke i ideološke) prilike vremena njihova nastanka. Zapostavljene su implicitne posljedice vanjskih pritisaka na leksikografiju - utjecaj ideologije na izbor izvora, stav autora prema jezičnom posuđivanju, definicijama i primjerima tipične upotrebe te prema promjenama stilskih odrednica. U daljnjim istraživanjima ovim bi područjima vrijedilo posvetiti više pozornosti. 


\section{Literatura}

Anić, Vladimir (1991, 1994, 1996, 1998, 2000, 2004) Rječnik hrvatskoga jezika, Novi Liber, Zagreb.

Anić, Vladimir (2003) Veliki rječnik hrvatskoga jezika, Novi Liber, Zagreb.

Broz, Ivan, Franjo Iveković (1901) Rječnik hrvatskoga jezika, Štamparija Karla Albrechta, Zagreb.

Daneš, František, Josef Filipec, Jaroslav Machač, Vladimír Mejstřík (1978, 1994, 2003, 2004, 2005, 2009) Slovník spisovné češtiny pro školu a veřejnost, Academia, Prag.

Dickins, Tom (2000) „Changing Ideological Directions: a Study of the Czech Dictionary Slovník jazyka českého (1937-1952)", Slavonica, 6: https:// www.tandfonline.com/doi/abs/10.1179/sla.2000.6.1.24, posjet 27. lipnja 2018.

Dickins, Tom (2012) „Historical 'Signposts' and Other Temporal Indicators in the Czech Lexicon", The Slavonic Studies and East European Review, 90, http://www.jstor.org/stable/10.5699/slaveasteurorev2.90.4.0601, posjet 27. lipnja 2018.

Havránek i sur. (1989) Slovník spisovného jazyka českého. Academia, Prag.

Hladká, Zdeňka (2005) „České slovníkářství na cestě k jednojazyčnému výkladovému slovníku", Naše řeč, 88, http://nase-rec.ujc.cas.cz/ archiv.php?lang=en\&art=7835. posjet 14. prosinca 2018.

Hujer i sur. (1935-1937) Příruční slovník jazyka českého. Česká akademie věd a umění, elektroničko izdanje, http://bara.ujc.cas.cz/psjc/ posjet 24. siječnja. 2019.

Jojić, Ljiljana i sur. (2015) Veliki rječnik hrvatskog standardnog jezika, Školska knjiga, Zagreb.

Jonke, Ljudevit i sur. (1967) Rječnik hrvatskosrpskoga književnog jezika, Matica hrvatska, Zagreb.

„O slovnících". LEXIKO - webové hnízdo o novodobé české slovní zásobě a výkladových slovnících. 2005. Zadnja izmjena 2011. https://lexiko.ujc. cas.cz/index.php.

Petrović, Bernardina (2006) „Hrvatska jednojezična leksikografija u 20. st.", Hrvatski jezik u 20. st., ur. Jelena Hekman, Ivo Pranjković, Marko Samardžija, Zagreb, 463-490. 
Šonje, Jure i sur. (2000) Rječnik hrvatskoga jezika, Leksikografski zavod Miroslav Krleža i Školska knjiga, Zagreb.

Tafra, Branka (2005) Od riječi do rječnika, Školska knjiga, Zagreb.

Trávníček, František., Váša, Pavel. $(1937,1946)$ Slovník jazyka českého, František Borový, Prag.

Trávníček, František (1952) Slovníkjazyka českého. Slovanské nakladatelství, Prag.

Vujić, Antun (2013) „Leksikografija, znanost i društvo. S dodatkom: 30 godina poslije" Studia lexicographica, 7, https://hrcak.srce.hr/133894, posjet 27. lipnja 2018.

\section{SUMMARY \\ Tena Šinjori \\ SOCIOLINGUISTIC ANALYSIS OF THE FOREWORDS IN CZECH AND CROATIAN MONOLINGUAL DICTIONARIES}

This paper takes a critical approach to understanding a dictionary as a neutral source of knowledge. A dictionary is studied as a collection of traces left in it by its authors and the society in which the dictionary is created.

The main aim of this study is to discover how the monolingual explanatory Czech and Croatian dictionaries reflect differences in social organisation of the two former socialist republics: Yugoslavia and Czechoslovakia. A sociolinguistic comparative analysis of the forewords of $\mathrm{Czech}$ and Croatian dictionaries published during the socialist period was carried out. Special attention was paid to the parts of the text referring to the social reality and circumstances related to the creation of each dictionary. The main hypothesis was that in Czech dictionaries more attention had been dedicated to socialism and its relations to lexicography, whereas in Croatian dictionaries the topic of language as an index of national identity had prevailed.

The analysis reveals differences in the status of lexicography in the two societies and describes extralinguistic (economic, ideological, political) impacts on lexicography. The results confirm the hypothesis that the topic of socialism is prevalent in Czech dictionaries, as opposed to the subject of nation being more present in Croatian dictionaries.

Key words: Czech Lexicography; Croatian Lexicography; Ideology; Socialism; Nation 